University of Nebraska - Lincoln

DigitalCommons@University of Nebraska - Lincoln

Publications from USDA-ARS / UNL Faculty

U.S. Department of Agriculture: Agricultural

Research Service, Lincoln, Nebraska

1981

Insecticides and Pheromones Used in the Midwest. A Short

Review

Evelyn Osbourne

USDA

Paul Schwartz

USDA

Follow this and additional works at: https://digitalcommons.unl.edu/usdaarsfacpub

Part of the Agricultural Science Commons

Osbourne, Evelyn and Schwartz, Paul, "Insecticides and Pheromones Used in the Midwest. A Short Review" (1981). Publications from USDA-ARS / UNL Faculty. 244.

https://digitalcommons.unl.edu/usdaarsfacpub/244

This Article is brought to you for free and open access by the U.S. Department of Agriculture: Agricultural Research Service, Lincoln, Nebraska at DigitalCommons@University of Nebraska - Lincoln. It has been accepted for inclusion in Publications from USDA-ARS / UNL Faculty by an authorized administrator of DigitalCommons@University of Nebraska - Lincoln. 


\title{
Insecticides and Pheromones Used in the Midwest. A Short Review
}

\author{
Evelyn M. Osborne* and Paul H. Schwartz \\ Agricultural Environmental Quality Institute, Chemicals Coordination Unit, AR, SEA, USDA, Beltsville, Maryland 20705
}

The Midwest produces most of the food and feed grains and oilseeds grown in the U.S. as well as a substantial proportion of a variety of other crops, but corn accounts for at least $75 \%$ of insecticide use in the region. The total amount of insecticides used on crops could be greatly reduced if economic losses from insects could be predicted accurately. We will examine the current status of chemical controls for insects of economic importance to this region, indicating some areas where new developments are needed or are likely to occur.

\section{Introduction}

The Midwest is commonly referred to as the nation's "breadbasket". From an agricultural point of view, it is not only an enormous granary, but a primary feedlot as well. For the most part, we will discuss the control of pest insects in food and feed crops of importance in the Midwest, but we will also consider some general tenets of insect control.

First, let us identify the area under discussion. For all practical purposes, the Midwest conveniently coincides with USDA's North Central Region, and the Department's Economics, Statistics, and Cooperatives Service (ESCS) collects data on individual states and three subareas in the North Central Region: (1) the Corn Belt, which includes Iowa, Missouri, Illinois, Indiana, and Ohio; (2) the Lake States of Michigan, Wisconisn, and Minnesota; and (3) the
Northern Plains, including North and South Dakota, Nebraska, and Kansas. In this presentation, "the Midwest" and "the North Central Region" will be considered to be synonymous.

Important Crops of the Midwest

Table I shows the importance of the North Central Region in U.S. production of feed grains. In 1977, the latest year for which statistics are available, it produced over $85 \%$ of the corn and oats, $70 \%$ of the commercially slaughtered hogs, and $51 \%$ of the commercial beef. The region also produces a significant proportion of food grains and oilseeds, including an impressive $71 \%$ of the soybeans and nearly all the flax and sunflower seed. Products not shown in the table include sugarbeets, $46 \%$; edible dried beans, $55 \%$; cranberries, $41 \%$; honey, $43 \%$; and popcorn, $91 \%$. 
Table 1. Proportion of Selected Major Commodities Produced in Subareas of the North Central Region, $1977^{a}$

\begin{tabular}{|c|c|c|c|c|c|c|c|c|c|c|c|c|}
\hline \multirow{4}{*}{$\begin{array}{l}\text { subareas of North } \\
\text { Central region } b\end{array}$} & \multicolumn{12}{|c|}{ percent of indicated commodity } \\
\hline & \multicolumn{5}{|c|}{ feed } & \multirow{2}{*}{\multicolumn{2}{|c|}{ livestock }} & \multirow{2}{*}{\multicolumn{2}{|c|}{ food grains }} & \multirow{2}{*}{\multicolumn{3}{|c|}{ oilseeds }} \\
\hline & & & & & & & & & & & & \\
\hline & corn & oats & barley & ghum & hay & hogs & cattle & wheat & rye & soybeans & flax & sunflower \\
\hline $\begin{array}{l}\text { Corn Belt } \\
\text { Lake States } \\
\text { Northern Plains }\end{array}$ & $\begin{array}{l}54.2 \\
16.9 \\
14.8 \\
\end{array}$ & $\begin{array}{l}19.1 \\
34.2 \\
32.2 \\
\end{array}$ & $\begin{array}{r}0.4 \\
13.7 \\
31.0 \\
\end{array}$ & \begin{tabular}{r}
9.5 \\
\hdashline- \\
51.3 \\
\end{tabular} & $\begin{array}{l}17.3 \\
17.5 \\
17.0 \\
\end{array}$ & $\begin{array}{r}45.1 \\
15.6 \\
9.7 \\
\end{array}$ & $\begin{array}{r}19.9 \\
8.1 \\
23.1 \\
\end{array}$ & $\begin{array}{r}13.2 \\
8.3 \\
36.8 \\
\end{array}$ & $\begin{array}{r}6.5 \\
18.8 \\
39.2 \\
\end{array}$ & $\begin{array}{r}66.8 \\
9.2 \\
4.7 \\
\end{array}$ & $\begin{array}{l}\ldots \\
21.1 \\
78.1 \\
\end{array}$ & $\begin{array}{l}-. \\
29.2 \\
64.7 \\
\end{array}$ \\
\hline total & 85.9 & 85.5 & 45.1 & 60.8 & 51.8 & 70.4 & 51.1 & 58.3 & 64.5 & 70.7 & 99.2 & 93.9 \\
\hline
\end{tabular}

${ }^{a}$ Based on total production in the U.S. per USDA Agricultural Statistics, 1979. ${ }^{b}$ Corn Belt includes Iowa, Missouri, Illinois, Indiana, and Ohio. Lake States includes Michigan, Wisconsin, and Minnesota. Northern Plains includes North Dakota, South Dakota, Nebraska, and Kansas.

In terms of acreage, the major crops of the Corn Belt and the Lake States are corn, pasture and range, soybeans, alfalfa, and wheat in about that order. The situation is different in the Northern Plains, where pasture and range, wheat, corn, other grains, and sorghum predominate. For the North Central Region as a whole the order is roughly as follows: pasture and range, corn, wheat, soybeans, other grains, and alfalfa.

\section{Losses Caused by Major Insect Pests in the Midwest}

Information concerning losses caused by insect pests is difficult to obtain. Losses will vary from year to year. They are dependent upon pest population densities, weather, other environmental factors, and capability of the grower to control infestations.

In an attempt to arrive at loss estimates, Schwartz and Klassen (1981) have reviewed data from field studies published in the Journal of Economic Entomology from 1942 through 1978 and in Insecticide and Acaricide Tests from 1976 through 1978 where the studies contained information on yield data from insecticide-treated and untreated plots. The authors calculated a percent yield loss with and without treatment to control a given pest by assuming a linear relationship between pest density and yield loss. We have taken some of the major pests for selected crops grown in the Midwest and used the information from Schwartz and Klassen on yield losses to estimate potential savings per acre when pests were controlled. These calculations (Table II) indicate that pest populations can develop to sufficient numbers to cause the percentage yield losses shown. Field crops are not high value per acre crops, and it does not usually pay to control insects on a field-to-field basis. Still, if entire pest populations could be suppressed, even low levels of damage over wide areas could be reduced economically or prevented. However, all pests shown are considered economically important with potential for high yield losses, and treatment is ordinarily required when economic threshold levels of the pest are exceeded.

For example, let us consider three of the most important field crops grown in the North Central Region: corn, soybeans, and alfalfa.

Corn. Rootworms and cutworms are generally conceded to be the most critical problem insects in the Midwest. Recent studies (Jackson, 1980) have shown that the persistent chlorinated hydrocarbons formerly used reduced corn rootworms to about one emerging adult/plant. The less persistent insecticides now in use produce equivalent yields but permit survival of about 10 emerging adult rootworms/plant. Thus, the infestation grows and spreads. The explanation given for the sustained yields is that early larvae are killed while the plant is young and vulnerable so yields are not affected, but larvae hatched later in the season survive because short-lived organophosphates and
Table II. Losses Caused by Some Major Pests of Crops Grown in the Midwest

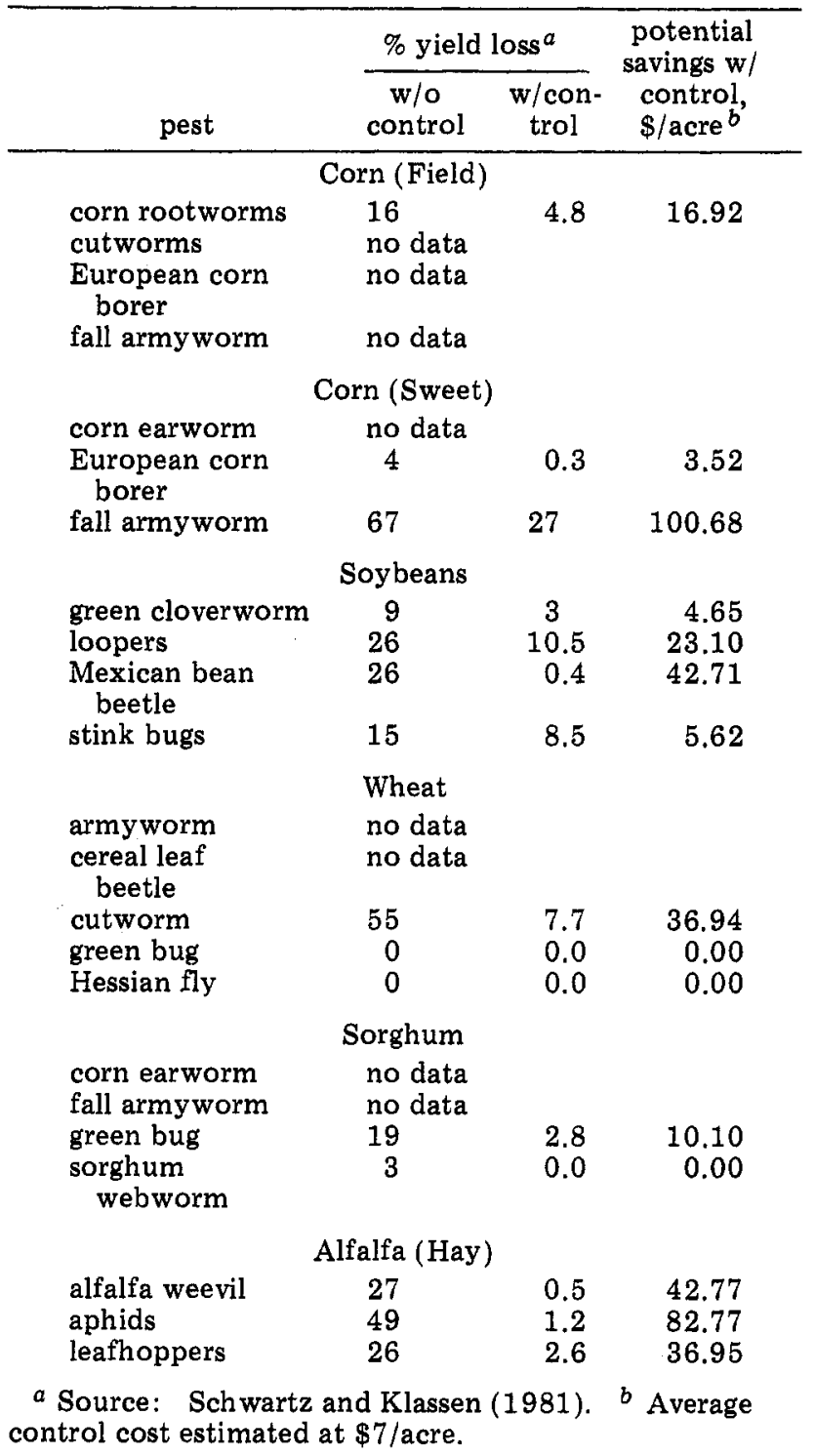

carbamates will already have been degraded. This may be the general pattern for such other soil insects as wireworms, white grubs, and cutworms, as well as for grasshoppers, and there are no insecticides of seasonal persistence.

Estimates of losses and control costs are also made by USDA's Animal and Plant Health Inspection Service (APHIS) from weekly reports of crop conditions as supplied by survey entomologists in the various states. The year-end summary of conditions for the 1979 corn crop (USDA Cooperative Plant Pest Report, 1980) indicate that about 800000 ha in Minnesota were treated at planting 
Table III. Trends in Insecticide Use in Subareas of the North Central Region, 1966-1976 ${ }^{a}$



Table IV. Quantities of Insecticides Used on Major Field Crops and Hay and Forage by Use and Area, $1976^{a}$

\begin{tabular}{|c|c|c|c|c|c|}
\hline & \multicolumn{4}{|c|}{ Ib active ingredient used in indicated area $(x 1000)$} & \multirow[b]{2}{*}{$\begin{array}{l}\text { \% total lb } \\
\text { used on crop in U.S. }\end{array}$} \\
\hline & Corn Belt & Lake States & $\begin{array}{l}\text { Northern } \\
\text { Plains }\end{array}$ & $\begin{array}{c}\text { total, North } \\
\text { Central region }\end{array}$ & \\
\hline $\begin{array}{l}\text { corn } \\
\text { wheat } \\
\text { sorghum } \\
\text { other grain } b \\
\text { soybeans } \\
\text { alfalfa } \\
\text { other hay and forage }\end{array}$ & $\begin{array}{r}14091 \\
481 \\
300 \\
\ldots 1 \dot{115} \\
725 \\
3\end{array}$ & $\begin{array}{r}5003 \\
14 \\
\ldots \\
20 \\
22 \\
100 \\
11\end{array}$ & $\begin{array}{r}8172 \\
395 \\
2199 \\
48 \\
2 \\
196 \\
1\end{array}$ & $\begin{array}{r}27266 \\
890 \\
2499 \\
48 \\
139 \\
1021 \\
15\end{array}$ & $\begin{array}{r}85.3 \\
12.3 \\
54.3 \\
2.6 \\
1.8 \\
18.9 \\
1.6\end{array}$ \\
\hline
\end{tabular}

a Source: Eichers et al. (1978). 'b Oats, rye, and barley.

time at a cost of $\$ 17.50 /$ ha for a total of $\$ 35$ million to control northern and western corn rootworm larvae. Wisconsin had three times more adult rootworms than in 1978 and the insecticides used performed poorly. Insecticides also failed in Illinois, perhaps because of lack of moisture to activate the chemicals, but good growing conditions prevented serious difficulties and fewer acres required treatment. In Indiana, rootworm pressure was about the same as in 1978 and an estimated $45 \%$ of the corn acreage was treated.

Iowa suffered extensive damage from black cutworms in 1979, but both Iowa and Illinois fared better than in 1978. European corn borer overwintered 1978 well, but subsequent climatic conditions prevented appreciable economic impact, and insecticide controls worked. Armyworms inflicted extensive damage in Michigan because they were detected late and chemical treatments gave variable performance. Such summaries illustrate some of the difficulties in predicting potential for crop loss and achieving adequate control.

Soybeans. With soybeans it is important to spare beneficial insect predators and parasites by withholding chemical treatments as long as possible. Research has shown that soybeans can sustain considerable loss of foliage before yields are affected. They can also compensate for pod loss at the earlier stages of pod formation but cannot fully replace lost pods when damage occurs after the early budding stages (Thomas et al., 1976).

Alfalfa. In 1979 the Lake States experienced unexpected increases in alfalfa weevils (USDA Cooperative Plant Pest Report, 1980). The slow-starting growing season probably contributed to adult survival. While parasitic wasps were present in sufficient numbers to be effective in Minnesota, chemical treatments were required in Wisconsin, especially after the first cutting. Treatments would also have been profitable in some areas of Indiana.

In Michigan the most damaging insect on alfalfa was the armyworm; it was detected too late for good control. Grasshoppers were second to the armyworm. Controls were effective, but mild fall weather in 1979 indicates higher populations in 1980. Potato leafhopper was the worst pest in Illinois and Indiana. Chemical treatment would have been profitable in some areas before the second cutting.

In March 1980 a USDA advisory news release (USDA 565-80) warned that surveys conducted in the fall of 1979 show the potential for severe grasshopper infestation in 1980. Economic damage ( 8 insects $/ \mathrm{yd}^{2}$ ) may occur in over 9 million acres in the Northern Plains States. USDA's Cooperative Rangeland Grasshopper Control Program treated 7.2 million acres during 1979 , and it is anticipated that 32 million acres in 17 states may need treatment in 1980.

\section{Insecticide Use}

From the standpoint of insecticide use, corn is clearly the principal crop treated (Table III). From data reported by ESCS from 1964 through 1976, we see that increased usage since 1966 is related to increased plantings in the Lakes and Plains States. The percentage of corn acreage treated remained relatively constant at $40-43 \%$ and at a rate of about $1 \mathrm{lb} /$ acre. We could find no such trends for other major crops of the region.

Some "lesser" crops were, in fact, more heavily dependent upon insecticides than corn. For instance, where data were available (1966 and 1971), apples and other fruits and nuts received treatment on from 67 to $100 \%$ of their acreage; the exception was other deciduous fruits in the Corn Belt, where only $33 \%$ of the acreage was treated. In 1976 and 1977,42 to $98 \%$ of the acreage planted to potatoes and other vegetables also received treatment.

The 27 million pounds of insecticides applied to corn in the North Central Region in 1976 represents $85 \%$ of all insecticides used on corn in the U.S. (Table IV). In contrast, the amounts used on sorghum and alfalfa are relatively small, though comprising a sizable proportion of the quantities used throughout the country.

It might be instructive to take a closer look at the kinds of insecticides employed on major field crops (Table V). Although chlorinated hydrocarbons were still available in 
Table V. Types of Insecticides Used on Major Field Crops, Hay, and Pasture and Range in the North Central Central Region, $1976^{a}$

\begin{tabular}{|c|c|c|c|c|}
\hline \multirow[b]{2}{*}{ insecticide } & \multicolumn{4}{|c|}{$\mathrm{lb}$ active ingredient used in indicated area $(\times 1000)$} \\
\hline & Corn Belt & Lake States & Northern Plains & $\begin{array}{l}\text { total, North } \\
\text { Central region }\end{array}$ \\
\hline \multicolumn{5}{|l|}{ carbamates } \\
\hline $\begin{array}{l}\text { carbofuran (Furadan) } \\
\text { carbaryl (Sevin) }\end{array}$ & $\begin{array}{r}2194 \\
426\end{array}$ & $\begin{array}{r}1739 \\
54\end{array}$ & $\begin{array}{l}2874 \\
1566\end{array}$ & $\begin{array}{l}6807 \\
2046\end{array}$ \\
\hline \multicolumn{5}{|l|}{ organophosphates } \\
\hline phorate (Thimet) & 3560 & 985 & 1138 & 5683 \\
\hline fonofos (Dyfonate) & 2323 & 1049 & 1512 & 4884 \\
\hline terbufos (Counter) & 2001 & 171 & 229 & 2401 \\
\hline parathion & $\ldots$ & 12 & 1133 & 1135 \\
\hline diazinon (Diazinon) & 689 & 207 & & 896 \\
\hline disulfoton (Di-Syston) & & & 837 & 837 \\
\hline methyl parathion & 315 & 15 & 319 & 649 \\
\hline malathion & 200 & $\ldots$ & 448 & 648 \\
\hline \multicolumn{5}{|l|}{ organochlorines } \\
\hline heptachlor & 1569 & 31 & $\cdots$ & 1600 \\
\hline chlordane & 568 & 748 & $\ldots$ & 1316 \\
\hline aldrin & 756 & 32 & 65 & 853 \\
\hline toxaphene & 594 & 11 & 52 & 657 \\
\hline
\end{tabular}

a Source: Eichers et al. (1978).

Table VI. Domestic Production of Insecticides, $1978^{a}$

\begin{tabular}{|c|c|c|c|c|}
\hline year & $\begin{array}{l}\text { total sales, } \\
\$(\times 1000)\end{array}$ & $\begin{array}{l}\text { total lb of } \\
\text { active } \\
\text { ingredients } \\
(\times 1000)\end{array}$ & $\begin{array}{c}\text { cost/ } \\
\mathrm{lb}\end{array}$ & $\begin{array}{l}\text { no, of } \\
\text { active } \\
\text { ingre- } \\
\text { dients }\end{array}$ \\
\hline $\begin{array}{l}1974 \\
1975 \\
1976 \\
1977 \\
1978\end{array}$ & $\begin{array}{l}375945 \\
456094 \\
513994 \\
639640 \\
743908\end{array}$ & 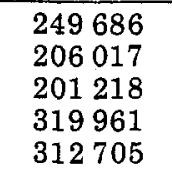 & $\begin{array}{l}1.51 \\
2.21 \\
2.55 \\
2.00 \\
2.38\end{array}$ & $\begin{array}{l}61 \\
58 \\
61 \\
70 \\
66\end{array}$ \\
\hline
\end{tabular}

a Source: National Agricultural Chemicals Association Industry Profile Survey 1978 conducted by Ernst and Ernst, Washington, D.C.

1976, organophosphorus compounds as a class had the greatest use, followed by carbamates. For quantities of specific compounds, it was carbofuran $>$ phorate $>$ fonofos $>$ terbufos. However, terbufos was a new development in 1976-indeed, the only new development listed. Carbofuran and fonofos were introduced in 1967; otherwise, all insecticides listed date from the 1950's or earlier. Plainly the insecticide industry is a mature industry, and approved chemicals that become established tend to retain their standing, barring special problems. Part of this static conditions is cost: old materials are generally cheaper though complete pricing data are difficult to obtain. For example, in March 1980, carbaryl, malathion, or parathions cost the farmer only $\$ 2$ to $\$ 3$ per pound of active ingredient. New products, even if more effective, meet stiff competition in the marketplace unless they fill a demonstrated need.

\section{The Insecticide Market}

Chemical companies with established pesticide markets are, by all accounts, healthy. According to a 1978 industry profile prepared by Ernst and Ernst for the National Agricultural Chemicals Association on the basis of data from 36 reporting companies (Table VI), total insecticide sales in dollars appear to be increasing linearly. Assuming that this trend continues into 1980 , sales would approach $\$ 1$ billion. However, recent data from ESCS (Eichers, 1980) indicate that demand for insecticides on crops other than cotton is expected to be about the same as in 1979, and prices will average only about $10 \%$ higher. OPEC price increases are expected to have only limited effect on feedstock chemicals though rather more on solvents (20-25\% higher) and fuels.

A similar survey was conducted among international marketers of crop protection chemicals by "Farm Chemicals" magazine (September 1979). They reported insecticide usage at $\$ 809$ million in the U.S. during 1978, estimated increases of $9.6 \%$ in 1980 (constant dollars), and further increases of $20 \%$ between 1980 and 1984.

\section{Insecticide Research and Development in \\ Industry}

Companies included in the 1978 domestic survey by Ernst and Ernst report that they are spending about 8\% of their sales for research and development. Insecticides account for about $35 \%$ of the expenditures for new product development and for about $29 \%$ of the expenditures for product expansion. Of the amount expended for new product development for all pesticides, approximately $33 \%$ is used for synthesis and screening activities, $22 \%$ for pilot field testing and formulation development, and $13.5 \%$ for toxicology, metabolism studies, residue analysis, and environmental chemistry. The remainder is spent on such items as registration, administrative overhead, and all other costs. For this effort, 3 of the 36 companies reported new products registered in 1977 or 1978 , and in each of those years, two new pesticide products were actually registered.

\section{Classes of Insecticides}

Let us look at some of the products now available or under development. Obviously, we cannot show all significant compounds, but those selected for discussion and comparison are considered to be representative. Proprietary names are indicated in parentheses. Dates of introduction are approximate.

Carbamates.
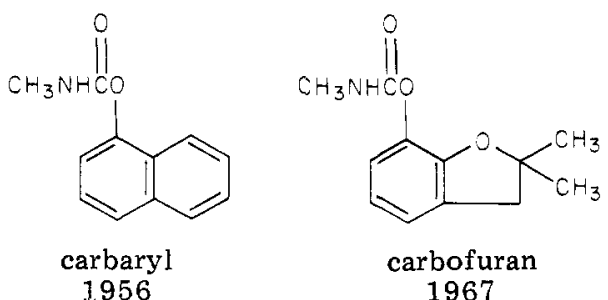

carbofuran 1967

Carbaryl, the first of the modern carbamates, is a contact insecticide registered for use on a wide variety of fruit, 
vegetable, and other crops; carbofuran is a broad spectrum soil and foliar insecticide and acaricide.<smiles>CNC(=O)C(C)(C)C</smiles>

aldicarb (Temik) 1956

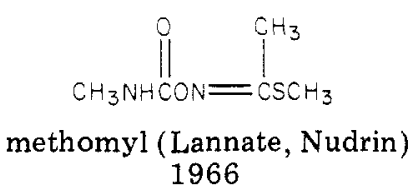
1966<smiles>CC(C)=NC(=O)N(C)SN(C)C(=O)C(C)(C)C</smiles>
1978 thiodicarb (Larvin)

Aldicarb is a systemic insecticide and acaricide also used as a soil insecticide, whereas methomyl is used primarily as a foliar treatment for such pests as loopers, armyworms, aphids, and leaf perforators. Thiodicarb is a broad spectrum compound closely related to methomyl, but of greater persistence and less phytotoxicity. It is said to be effective against cutworms.

\section{Organophosphates.}

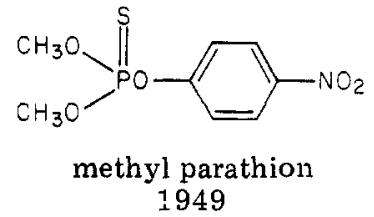

1949

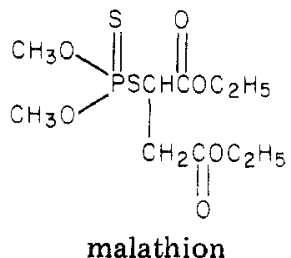

1950
Methyl parathion is a contact insecticide and stomach poison of high toxicity but low persistence; malathion is both an insecticide and acaricide and is widely used because of its relative safety to mammals.

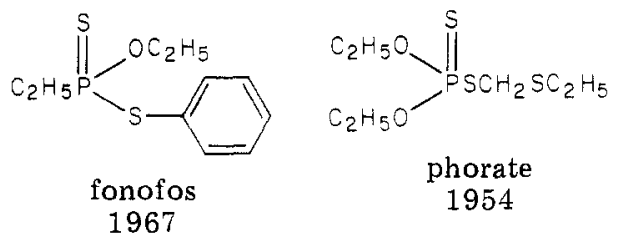

$$
\begin{gathered}
\mathrm{C}_{2} \mathrm{H}_{5} \mathrm{O} \\
\mathrm{C}_{2} \mathrm{H}_{5} \mathrm{O}
\end{gathered}
$$

Phorate is a systemic and contact insecticide as well as a soil insecticide for various crops. Residual activity against soil insects is increased in its homologue terbufos. Fonofos, one of the few phosphonate insecticides, is also used against soil insects; it persists for about 8 weeks.

$$
\begin{gathered}
\text { acephate (Orthene) } \\
1969
\end{gathered}
$$

Acephate is a systemic lasting about 10 to 15 days on foliage that is active against a wide range of aphids, thrips, leafminers, and lepidopteran larvae. It can be used safely on many crop plants.<smiles>CCCCCCN(CCCC)c1cc(C)cc(P(=S)(OC)OC)n1</smiles>

chlorpyrifos (Lorsban) 1965

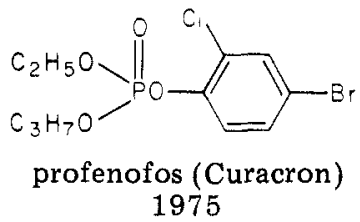

1975

$$
\text { pirimiphos-methyl (Actellic) }
$$
1970

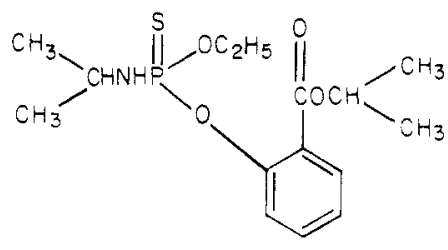

isofenphos (Amaze) 1974
Chlorpyrifos is effective by contact, ingestion, and vapor action and is used as a foliar and soil insecticide. On the other hand, pirimiphos-methyl is a fast-acting insecticide-acaricide with fumigant action that shows promise against stored-product insects of grain. Profenofos is a foliar insecticide that is effective against lepidopteran larvae and sucking insects of field crops and vegetables. Isofenphos is a contact insecticide and stomach poison that shows some translocation from roots and is considered promising against a range of soil insects. This compound is an example of a chemical that waited 10 years for a market to materialize in the U.S. Our agency first received it for evaluation in 1969 as Oftanol, but it apparently took the soil insect problem to justify development.

Pyrethroids.
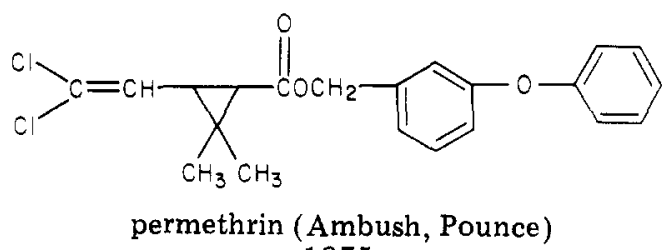
1975<smiles>CC(C)C(=O)C(c1ccc(Cl)cc1)C(C)C</smiles>

fenvalerate (Pydrin) 1976

Permethrin, the first of the "photostable" pyrethroids, was soon followed by fenvalerate. Both received conditional registration for use in 1979 against resistant budworms. The materials are effective as contact insecticides on many crops at rates of $0.1-0.2 \mathrm{lb} / \mathrm{acre}$, and the favorable mammalian toxicity suggests eventual widespread use. The $\alpha$-cyano analogue of permethrin (cypermethrin) and the 4-difluoromethoxy analogue of fenvalerate (AC 222,705 ) are active at reduced dosage and are probable new developments. However, the introduction of a second or third chiral center on the benzylic carbon gives products of considerable complexity (rivaling the pheromones), and an increase in activity against insects is usually accompanied by a decrease in mammalian safety. Pyrethroids commonly exhibit repellency. Since they are generally not systemically active, their use is not recommended where resistant mites are a problem.

Insect Growth Regulators. 


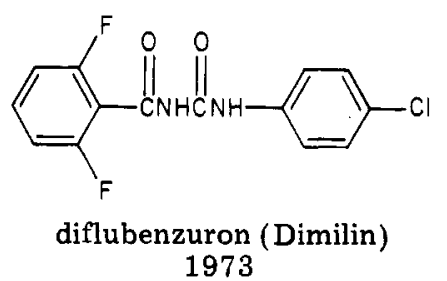

Diflubenzuron is an insect growth regulator-ovicide that inhibits chitin formation and disrupts metamorphosis. It is effective against many insects at $0.5-0.2 \mathrm{oz} /$ acre, and spares beneficial insects.

$$
\underbrace{\begin{array}{c}
\text { I, } \mathrm{R}_{1}=\mathrm{R}_{2}=\mathrm{C}_{2} \mathrm{H}_{3} \\
\text { II, } \mathrm{R}_{1}=\mathrm{CH}_{3} ; \mathrm{R}_{2}=\mathrm{C}_{2} \mathrm{H}_{5} \\
\text { III, } \mathrm{R}_{1}=\mathrm{R}_{2}=\mathrm{CH}_{3}
\end{array}}_{\text {JH }}
$$

Methoprene and similar compounds disrupt the developmental process through mimicry of the juvenile hormone (JH), which causes perpetuation of juvenile stages. Methoprene is registered for control of flies (Diptera). Chemists have worked extensive variations on all parts of the basic $\mathrm{JH}$ structure, from the length of the carbon chain to one or both ends of the molecules, and have produced a surprising assortment of analogues that have juvenilizing or antireproductive effects on one or more species of insects.

Other.<smiles>Cc1cc(Cl)ccc1N=CN(C)C</smiles>

chlordimeform (Galecron, Fundal) 1971

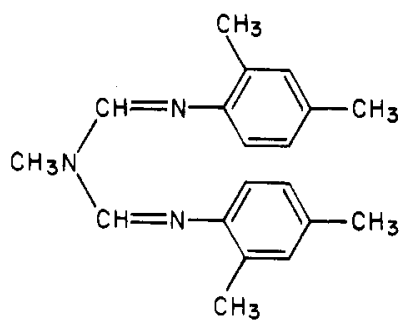

amitraz (Baam)
The amidine insecticides/acaricides/ovicides produce a variety of effects in insects. However, amitraz was questioned under RPAR for oncogenic effects and returned for registration against insects and mites only on pears. Chlordimeform, a very efficient ovicide on cotton, was voluntarily withdrawn by the manufacturer because of possible carcinogenicity but has since been allowed for use with protective equipment. The class has good activity against ticks.
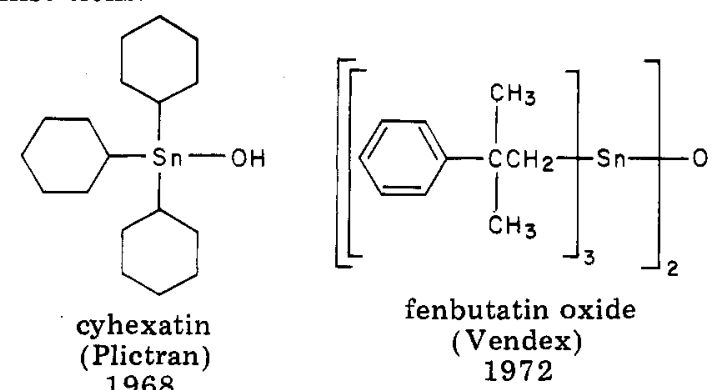

fenbutatin oxide

(Vendex) 1972
Table VII. Types of New Candidate Insecticides Submitted by Industry for Evaluation in USDA, SEA, Agricultural Research Laboratories, 1977-1979

\begin{tabular}{lccc}
\hline & \multicolumn{3}{c}{ no. submitted } \\
\cline { 2 - 4 } \multicolumn{1}{c}{ type } & 1977 & 1978 & 1979 \\
\hline organophosphates & 5 & 5 & 15 \\
carbamates & 2 & 4 & 12 \\
pyrethroids & 4 & 8 & 2 \\
ureides & 2 & 3 & 3 \\
anilines & 10 & 0 & 6 \\
miscellaneous & 13 & 18 & $\underline{19}$ \\
$\quad$ total & 36 & 38 & 57
\end{tabular}

Cyhexatin and fenbutatin oxide are recent examples of the tin acaricides, suitable for use against phytophagous mites of fruit trees.

\section{Cooperative Research on Agricultural Chemicals for Insect Control in USDA}

Research on chemical insect control in Agricultural Research, SEA takes diverse forms, but the principal objectives are (1) to cooperate with industry and others in the evaluation and development of safer, more effective insecticides, (2) to explore chemicals that modify insect behavior, and (3) to develop comprehensive strategies, including chemicals, for methods of managing insect populations that will have minimal impact on the environment. Entomological laboratories in the North Central Region that conduct evaluation research on new candidate insecticides include those at Ankeny, Iowa, Brookings, S.D., Manhattan, Kans., and Vincennes, Ind. Laboratories at other locations such as Yakima, Wash., Bozeman, Mont., and Tifton and Savannah, Ga., also work with crops or with insect pests of interest in the Midwest.

Generally speaking, candidate insecticides received from industry for evaluation are 1 to 3 years away from application for registration and have already undergone field and primary toxicological testing. Further evaluation in federal laboratories or state experiment stations produces independent corroborative data and extends the range of possible applications to new locations and other insect species. We have categorized the types of candidate insecticides submitted to AR laboratories by industry over the past 3 years in order to assess trends in research and development (Table VII). Organophosphorus compounds and carbamates are still being evaluated for selective uses, and a temporary increase in the number of candidates for a specific project, such as occurred in 1979, is not unusual. Pyrethroids have been the subject of renewed interest since the discovery of permethrin in 1973. Ureides and anilines are primarily materials that were originally synthesized as herbicides but have subsequently shown useful selective activity against insects. Perhaps two or three of the materials in the miscellaneous category are truly innovative. The fact is that the great majority of experimental chemicals will not be developed commercially. Most will be revealed in publications after a year or two and will then await a sizable market or a pressing need. For example, industry, USDA, and EPA made a maximum effort to push development of the pyrethroids to counter the resistance that was developing in Heliothis species on cotton-in this instance, it took only about 5 years from initial disclosure to conditional registration. Once a material is registered on a major crop, it becomes easier to extend the registration for certain minor and specialty uses.

State and federal scientists in the Midwest develop efficacy, residue, and phytotoxicity data which are utilized to support the establishment of pesticide residue tolerances from EPA and to amend existing pesticide labels in co- 
operation with the registrant. This effort is coordinated nationally under the Interregional Research Project entitled "A National Agricultural Program for Clearance of Pesticides for Minor or Specialty Uses" (IR-4 program). As a result of this program, many new resigrations of insecticides are being obtained to meet the needs of farmers and growers in the Midwest.

Experiments at Bozeman, Mont., with Nosema locustae have resulted in its registration for use against grasshoppers on rangeland at a critical time. The microsporidia of $N$. locustae are compatible with low doses of malathion (already in use) against grasshopper nymphs, and the effects of the two materials are additive. Also, when the spores were formulated on bran flakes with low rates of carbaryl, $50 \%$ of the grasshopper population was infected and $80 \%$ control was obtained at population densities of 10-30 hoppers/yd ${ }^{2}$. Investigators at Manhattan, Kans., are trying to adapt the microbial insecticide Bacillus thuringiensis for use against stored-grain insects and, in addition, have accumulated data for a petition on combustion of natural gas to $\mathrm{N}_{2}$ and $\mathrm{CO}_{2}$ to provide a controlled atmosphere on raw agricultural products that will suppress pest insects.

\section{Pheromones}

Another way to disrupt the life cycle of pest insects is to interfere with their chemical communication system. This system consists of "semiochemicals", the term applied to the chemical messengers that one organism presents to another; "pheromones" are chemical signals between individuals of the same species. The sex pheromones, which include some of the most biologically active chemicals known, are often effective in nanogram amounts. For regulatory purposes, such chemicals are classified as insecticides if used for insect control, even if, as is usually the case, the materials are innocuous to target and nontarget species. They are not so classified if they are used only for detecting or monitoring population densities. At this time, population monitoring is still the most important application for sex pheromones or attractants.

The use of pheromones is particularly effective with Lepidoptera, an insect order that includes caterpillars, borers, budworms, leafrollers, cutworms, loopers, armyworms, and similar species especially injurious to field crops, fruit and vegetable crops, and fruit and forest trees. Their sex pheromones are almost all long-chain unsaturated alcohols, acetates, or aldehydes, typically 12 to 16 carbons in length. For a time it was thought that each species might possess its own individual chemical and that this would isolate one species from others, but it soon became clear that certain $\mathrm{C}_{12}, \mathrm{C}_{14}$, and $\mathrm{C}_{16}$ monoene and diene compounds were being isolated from many species. Further, the biological activity could be potentiated or inhibited by similar compounds, frequently the cis or trans isomers. It now appears that most species depend on blends of several compounds for mating.

Isolation and identification techniques have now progressed to the point that Klun et al. (1979) were able to analyze and compare heptane washes of ovipositors from single females of Heliothis virescens (tobacco budworm) and Heliothis zea (variously known as corn earworm, tomato fruitworm, or bollworm). They found four components that were common to the pheromones of the two species $-Z-7, Z-9$, and $Z-11$ hexadecenals and hexadecanal. In each case the main component was $(Z)$-11-hexadecenal (range 81-96\%). For $H$. virescens, however, there were three additional trace chemicals: (Z)-9-tetradecenal, tetradecanal, and $(Z)$-11-hexadecen-1-ol. Earlier investigators (Roelofs et al., 1974; Tumlinson et al., 1975) had shown
Table VIII

\begin{tabular}{|c|c|c|}
\hline diptera & \multicolumn{2}{|c|}{ coleoptera } \\
\hline house fly & \multicolumn{2}{|c|}{$\begin{array}{l}\text { Japanese beetle } \\
\text { khapra beetle }\end{array}$} \\
\hline \multicolumn{3}{|c|}{ lepidoptera } \\
\hline $\begin{array}{l}\text { European corn } \\
\text { borer } \\
\text { fall army worm } \\
\text { corn earworm } \\
\text { codling moth }\end{array}$ & $\begin{array}{l}\text { peachtree borer } \\
\text { lesser peachtree } \\
\text { borer } \\
\text { peach twig borer } \\
\text { grape berry moth }\end{array}$ & $\begin{array}{l}\text { alfalfa looper } \\
\text { cabbage looper } \\
\text { potato tuberworm } \\
\text { Indianmeal moth }\end{array}$ \\
\hline
\end{tabular}

that the principal chemical $(Z)$-11-hexadecenal alone attracts males of neither species to traps, but a 16:1 mixture with $(Z)-9$-tetradecenal was sufficiently active to trap some $H$. virescens males. Field bioassays in 1978 confirmed the weak activity of the 16:1 mixture and showed, by contrast, that the full complementary mix for each species equalled or exceeded the attraction of single virgin females. Males were attracted only to the synthetic mixture that was representative of their own species, even though both species were present. From these results, the authors suggested the existence of a congeneric "theme", whereby trace chemicals provide the separation necessary to sustain the individual species.

Mitchell et al. (1976) reported that (Z)-9-tetradecen-1-ol formate, which is not a component of either Heliothis pheromone, can disrupt the mating of both species while the acetate effectively disrupts mating of the fall armyworm. They estimated that these chemicals, if applied together to sweet corn at rates of $50 \mathrm{~g} /$ ha could reduce the need for applied insecticides by $50 \%$ or more. The fall armyworm pheromone has been identified as $(Z)$-9-dodecen-1-ol acetate, a chemical that is also common to several species. Could this be another "theme" chemical?

The burgeoning interest in sex pheromones has been remarkable. In the preface to the revised edition of his book on insect sex pheromones, Jacobson (1972) noted that 37 had then been identified. Today sex pheromones for at least 68 economically important insect pests in the U.S. have been identified and at least another 9 are nearing characterization. In addition, nonpheromone attractants are known for at least 14 species; in some cases these materials may be more practical than a natural product (cost, stability). Also, not all insects are dependent upon pheromones for mating. For at least 46 species, an operational attractant is in use for detection or survey. Some of these which are of interest in the Midwest are listed in Table VIII.

The Pesticide Research Center at Michigan State University maintains a state-wide monitoring program with pheromone traps for the codling moth and the redbanded leafroller to predict the times when spraying should be done and to conduct model studies (Minks, 1979). The Stored Product and Household Insect Laboratory at the University of Wisconsin supplies the khapra beetle pheromones used by USDA's Animal and Plant Health Inspection Service to detect these pests at major coastal ports of the U.S.A. and Mexico and in warehouses. USDA's Insect Attractants, Behavior, and Basic Biology Research Laboratory at Gainesville, Fla., is responsible for a largescale monitoring program to determine the potential migration of adult populations of the fall armyworm (Mitchell, 1979). This destructive pest overwinters in Florida and southern coastal states and migrates each year as far north as Canada and as far west as Montana. If the spring is cold and wet so that corn is planted late, unforeseen losses from the fall armyworm may reach as much as $\$ 500$ million. 
Table IX

\begin{tabular}{|c|c|c|c|}
\hline diptera & \multicolumn{2}{|l|}{ coleoptera } & homoptera \\
\hline $\begin{array}{l}\text { maggots } \\
\text { Hessian fly }\end{array}$ & \multicolumn{2}{|c|}{$\begin{array}{l}\text { wireworms } \\
\text { rootworms } \\
\text { white grubs } \\
\text { Colorado potato beetle } \\
\text { Mexican bean beetle } \\
\text { sunflower stem weevil } \\
\end{array}$} & $\begin{array}{l}\text { leafhoppers } \\
\text { pear psylla } \\
\text { whiteflies } \\
\text { scales }\end{array}$ \\
\hline hemiptera & hymenoptera & \multicolumn{2}{|c|}{ lepidoptera } \\
\hline $\begin{array}{l}\text { plant bugs } \\
\text { stink bugs }\end{array}$ & wheat stem sawfly & \multicolumn{2}{|c|}{$\begin{array}{l}\text { armyworm } \\
\text { cutworms } \\
\text { velvetbean caterpillar } \\
\text { tomato pinworm } \\
\text { green cloverworm }\end{array}$} \\
\hline
\end{tabular}

Obviously the proper formulation of sex attractants is essential to successful utilization. The active chemical(s) must be released at a rate that is effective over as long a period as possible; mixtures should not disproportionate, and sensitive structures (aldehydes, double bonds) require protection. Thus the system for dispensing pheromones is very important. Various emission devices have been tested, and two that have been particularly promising are the Hercon three-layer laminated plastic dispensers and the Conrel hollow fibers.

Recent actions for registration of pheromones or attractants of interest to the Midwest include the following: (1) Japanese beetle pheromone $((R)-(Z)$-5-(1-decenyl)dihydro-2(3H)-furanone) for trapping adult insects, registered June 1979; (2) gypsy moth pheromone (disparlure; cis-7,8-epoxy-2-methyloctadecane) for use on forest and shade trees, registered August 1979; (3) pheromones of the peachtree borer and lesser peachtree borer $((Z, Z)$ - and $(E, Z)$-3,13-octadecadien-1-ol acetate) application for registration for use on various fruit trees; (4) aggregating attractant of the elm bark beetle (4.9\% 4-methyl-3-heptanol, 1.9\% 2,4-dimethyl-5-ethyl-6,8-dioxabicyclo[3.2.1]octane, and $14.2 \%$ cubebene) application for registration as an insecticide.

While research on insect pheromones and attractants is making rapid progress, there are several important insect pests of crops for which potent attractants are needed (Table IX).

\section{Future Prospects}

What are the future prospects for insecticides and pheromones in insect control? We cannot claim omniscience or clairvoyance. Decisions on pesticides, and especially insecticides, are not made solely on the basis of scientific results; law, custom, public policy, and economics are also involved. Overall, currently available insecticides are adequate for most uses if one assumes wider use of pyrethroids and growth regulators. There is a need for more effective soil insecticides that have extended residual activity, as indicated earlier, and some new ones are being developed. Registration for minor uses is still a weak spot, but IR-4 has been relatively effective in developing petitions with federal and state aid. There is a dearth of good fumigating agents, and we would be very much interested in good candidates.

Integrated pest management (IPM) is stated public policy, and IPM programs will be increasingly accepted by farmers if they reduce production costs. It is said that IPM is not new, but certainly the emphasis on and funding for demonstration programs are new. Pheromones seem destined to fit into the IPM system easily as problems of identification and formulation are solved. IPM will also include cultural controls such as tillage or trap crops where feasible. Biological controls too will assume increasing importance whenever predators, parasites or pathogens can be established or resistant plants can be developed. For example, there has been good progress in introducing wheat that is resistant to the Hessian fly and corn that is unpalatable to borers. Parasites of the alfalfa weevil already save eastern U.S. farmers an estimated $\$ 7$ million annually in insecticide costs (USDA 674-80), and insectaries are now planned for Minnesota, Wisconsin, Iowa, Missouri, Illinois, and Indiana. Bacillus thuringiensis has been available since 1962 for use on lepidopteran larvae, and materials of biological origin will continue to achieve registration more easily than do chemical insecticides. Still, few will claim that any of these approaches alone or in combination can be adequate to maintain productivity reliably without the intervention of chemical insecticides. We cannot foresee a time when synthetic insecticides will not be needed.

There is nevertheless a sense that we have reached a turning point in insecticide research, that the reserve knowledge has been used up, and that any new approach awaits major breakthroughs in basic biochemistry, insect physiology, molecular biology, or drug design. Such advances would be welcome. But while we wait for these to occur, we continue to pursue the plodding progression of incremental knowledge from existing areas of research. One can never be sure about the origin of breakthroughs.

\section{Literature Cited}

Andrilenas, P. A. USDA-ERS Agricultural Economic Report No. 252, 1974. Andrilenas, P. A. USDA-ERS Agricultural Economic Report No. 268, 1975. Eichers, T. R. USDA-ESCS Agricultural Economic Report No. 454, 1980.

Elchers, T. R.; Andrilenas, P. A.; Anderson, T. W. USDA-ESCS Agricultural Economic Report No. 418, 1978.

Ernst and Ernst. "1978 Industry Profile Study", National Agricultural Chemical Association, Washington, D.C., 1979: PC-79-39, Schedules 2, 6-A-1.

"Farm Chemicals"; Meister Publishing Co.: Willoughby, Ohio, Sept 1979; 61. Jackson, R. D. NPS, AR, SEA, USDA, Beltsville, Md., Prlvate communication, 1980.

Jacobson, M. "Insect Sex Pheromone"; Academic Press: New York, 1972; Preface.

Klun, J. A.; Plimmer, J. R.; Blert-Leonhardt, B. A.; Sparks, A. N.; Chapman, O. L. Science 1879, 204, 1328.

Minks, A. K. "Status of the use of insect pheromones in agricultural practice", presented at IOBC-WPRS Symposlum on Integrated Control in Agriculture and Forestry, Vlenna, Austria, Oct 8-12, 1979.

Mitchell, E. R. Fla. Entomol. 1979, 62(2), 81.

Mitchell, E. R.; Baumhover, A. H.; Jacobson, M. Environ. Entomol. 1876, 5 , 484.

Roelofs, W. L.; Hill, A. S.; Cardê, R. T; Baker, T. C. Life Sci. 1974, 14, 1555. Schwartz, P. H.; Klassen, W. in "CRC Handbook of Pest Management in Agriculture", Vol. 1. Pimentel, D., Ed.; CRC Press, Inc.: Boca Raton, Fla., 1981; Chapter 1.

Thomas, G. D.; Ignoffo, C. M.; Smith, D. B. J. Econ. Entomol. 1976, 69, 737.

Tumlinson, J. H.; Hendricks, D. E.; Mitchell, E. R.; Doolittle, R. E.; Brennan, M. M. J. Chem. Ecol. 1975, 1, 203.

"USDA Agricultural Statistics 1979"; U.S. Government Printing Office: Washington, D.C., 1979.

USDA Cooperatlve Plant Pest Report (APHIS) 1880, 5, 53, 96.

USDA News Release 565-80, Mar 13, 1980

USDA News Release 674-80, Mar 31, 1980.

Received for review August 4, 1980 Accepted September 22, 1980

Presented at the Symposium on Agricultural Research in Areas of Special Interest, 14th Great Lakes Regional Meeting, ACS, Western Illinois University, Macomb, IIl., June 4, 1980. Mention of commercial products does not imply recommendation or endorsement by the U.S. Department of Agriculture over others not mentioned. 